\title{
World After Pandemic: New Socio-Psychological Complex Rises
}

\author{
Pandemiden Sonra Dünya: Yeni Sosyo-psikolojik Karmaşık Yükselişler
}

Easmin Akter Eva*

\begin{abstract}
Among the rapid and fast growing impact of the Covid-19 pandemic, many hidden realities of our daily lives have become complicated and apparent. Being in this pandemic era, it makes sense that prime focus should be on the sequential process of understanding, adjusting and coping with the running pandemic from a differently compatible perspective. By doing that, the everyday social management of pandemic has rigorously started to show how immensely this public health emergency issue has surfaced, been considered, managed and at times, even caused further marginalisation of sociohistorically disadvantaged groups that struggle hard to find proof in 'abled' society already. It is considered that the Covid-19 pandemic as a super transition to a more inclusive society in the newly found spirit of collective action and shared responsibility. Societies are finding alternative ways to reach their goals such as education, seminars, meetings are provided online. People go out after taking necessary preparations like putting on masks and maintaining social distance to protect themselves and others. It has become a new normal thing and it will be passed onto the world after this pandemic thoroughly. We are getting used to a new normality. We are bound to step out only with proper equipment like masks. This is our call as a community, this is our ethical and moral compass which should be leading us in this period of reconstruction. It entangles every social realm, more and more countries are on restricted mode and some are on total shut down mode which boldly affect education, health care, economic sectors, business world, domestic spheres and what not! Anxiety, depression, crime, domestic violence, increasing divorce rate; these all came voluntarily with this pandemic as a package. To deal with a bizzare like that, it is taking all of us a lot to cope up with, to survive through this.
\end{abstract}

Keywords: New normal, booming of online scopes, psychological effects, societal complexity.

\footnotetext{
* Yüksek Lisans Öğrencisi, Sakarya Üniversitesi, Fen-Edebiyat Fakültesi, Sosyoloji Bölümü, easmin.eva@ogr.sakarya.edu.tr
}

Bu makale iThenticate sistemi tarafından taranmıştır.

Makale Gönderim Tarihi: 6 Kasım 2020 


\section{Öz}

Covid-19 salgınının hızlı ve hızla büyüyen etkileri arasında, günlük hayatımızın birçok gizli gerçekliği karmaşık ve görünür hale geldi. Bu pandemi çağında yaşarken, odaklanılması gereken şey, devam eden pandemiyi farklı bir şekilde uyumlu bir perspektiften anlama, ona uyum sağlama ve onunla başa çıkma çabası olmalıdır. Bunu yaparken, bir taraftan da pandeminin gündelik hayattaki toplumsal yönetilme biçimi, bu aciliyet arz eden halk sağlı̆̆ 1 sorununun ne kadar devasa bir şekilde su yüzüne çıktığını, ele alındığını, yönetildiğini ve hatta zaman zaman zaten 'sağlıklı' toplum içerisinde kendisine bir yaşam temin etme konusunda toplumsal ve tarihsel anlamda dezavantajl konumda bulunan grupların daha da marjinalleşmelerine sebep olduğunu sert bir şekilde yüzümüze çarpmıştır. Covid-19 salgınının, yeni yakalanan kolektif eylem ve ortak sorumluluk ruhu içinde daha kapsayıcı bir topluma hızlı bir geçiş olduğu düşünülmektedir. Toplumlar eğitim, seminerler, toplantılar gibi hedeflerine ulaşmak için alternatif yollar buluyorlar, örneğin bu gibi imkânlar çevrimiçi olarak sunuluyor. İnsanlar kendilerini ve başkalarını korumak için maske takmak, sosyal mesafeyi korumak gibi gerekli hazırlıkları yaptıktan sonra dışarı çıkıyorlar. Bunlar yeni normal haline geldi ve pandemi den sonra dünyaya tamamen yayılacak. Yeni bir normalliğe alışıoruz. Sadece maske gibi uygun ekipmanlarla dışarı çıkmamız gerekiyor. Topluluk olarak bu çağrımız, bu yeniden yapılanma sürecinde bize yol göstermesi gereken etik ve ahlaki pusulamızdır. Bu durum bütün sosyal alanları içine alıyor ve gittikçe daha fazla ülke kısıtlamalar içerisinde ve bazıları tamamen kapanma halinde yaşıyor. Bu da eğitimi, sağlık hizmetlerini, ekonomik sektörleri, iş dünyasını, hane halkının ev içindeki yaşamını ve daha birçok şeyi etkiliyor. Kaygı, depresyon, suç, aile içi şiddet, boşanma oranının artması; bunların hepsi bu pandemi ile birlikte bir paket halinde gönüllü bir biçimde hayatımıza girdi. Daha önce eşi görülmemiş böyle tuhaf bir şeyle başa çıkmak ve bu süreçte ayakta ve hayatta kalmak hepimizin çok fazla çaba sergilemesini gerektiriyor. $^{\dagger}$

Anahtar Kelimeler: Yeni normal, çevrimiçi alanların hızla artışı, psikolojik etkiler, toplumsal karmaşıklık 


\section{Introduction}

COVID-19 not only brought significant changes in everybody's daily lives, but also huge impacts which are encountered worldwide, in almost every geographical part of the world. Everyone is at risk from coming in contact with the virus which brings insecurity and fear. The scrutiny and severity of the situation has become more crystal clear by experiencing physical isolation, travel restrictions, forcing people to not come out of home and managing their work, services, education and so on from online to avoid contraction and to pull down the spreading rate of the virus. By following those strict management plans and routes to take control over this havoc, people have experienced the highest rates of unemployment, disrupted global supply chains, closed businesses which have not been seen by people in most of the countries for decades. The World Health Organization has declared COVID 19 as pandemic officially on $11^{\text {th }}$ March 2020. After this catastrophic situation comes to a full stop, it is assumed that there will be huge changes with new perspectives and outlooks. A Gallup survey conducted in April found that three out of five workers who have been working from home during the pandemic would like to continue working remotely even after public health restrictions are lifted (Block S, June 5 2020). The fear and helplessness that people lived throughout this pandemic while having most advanced modern technology, people are left with less confidence and more vulnerability because it is taking lots of effort and time with all the technological power we have yet no proper solution to get rid of completely. On the other hand, new socio-psychological perspectives are bubbling up with new outlooks and realms of different dimensions. This pandemic has become a diagonal shifting elevator, it's on the way to blend everything and mould our life in a changed way. The way of greetings, public relationship and collaboration, public gatherings will take reformed shape and thus new-normality is taking over that space. As being aware of the Late Modernity, emerging infectious disease like Corona lacks direct proof of sustainability. This pandemic triggered every single realm of our sociological and psychological zone. But soon after this pandemic ends, we will get to observe numerous paradigm shifts in cultures and attitudes which we literally inhaled into our lives in that period of adjusting with Corona.After the pandemic gets over, nothing will be like before; as it has crushed our traditional socio-psychological phases and constructed a new-normal form of complexity which are rising rapidly.It will not feel awkward to see everyone keeping up with using masks, maintaining physical distances even after when pandemic is over. As the world has gone through a huge gap in manufacturing, producing and chain supply, companies are on verge to introduce easy and available solutions to get out of their problems. Thus, there will be 
thousands of gateways to get work and needs done as much as possible with the help of the internet. Online based service stations, work opportunities, educational systems will be launched more and more like booming and spreading worldwide. People will no longer be confident and fearless about the future as they used to be, before pandemic. It's getting settled in our socio-psychology that, despite having the newest technologies, we are helpless against Corona which the world could not fight back and diminish in a short period of time. The threat of Corona is located more because of the limited capacities for its medical treatment than the virus itself, the main vulnerability part started from here. Therefore, this virus demonstrates the basic problems of human life, suffering and unexpected death. On the other hand, the roots of pandemic traumatisation run more deeper than assumed. First of all, the rise of fear and insecurity; secondly, in the wake of pandemic threat and uncertainty and finally, our daily life routines and structures which are the source of stability and predictability become suspicious which make all these go towards disrupting experiences.

\section{Methodology}

Research community has responded rapidly toward this new threat to Humanity. Qualitative approaches are considered while conducting the paperwork; because document and data research seems potential to bring out the information I have been searching for. As survey, or any other statistical measurement was not used so, it has been far away from quantitative approaches. Using association secondary data and online books, articles, statistics and journals have been used as the information source of this article. Document studies have been chosen as themed methodology. The WHO has created a database of publications on Coronavirus disease which is publicly available. Interviews of professional expertise appeared on online channels by BBC, Guardian, DW Academy, World Economic Forum, UNESCO, UNICEF, UNDP and The Economist have been taken into major consideration while gathering the needed official information to judge the severity and rationality of this article. Quantitative approach would have been better to bring out the consequences of COVID 19 but the risks are also on high pitch in that context. Although, for the latest statistical updates about COVID; this article has relied on trusted information sources.

\section{Theoretical Perspective}

In my review of relevant literature, I have found two of the best theoretical frameworks that I could adopt in understanding the sociological relevance of the COVID-19 pandemic are the ones developed by Ulrich Beck. Ulrich Beck is the pioneer sociologist who always highlighted 
the topics of risk, hazards and threats and how it may have a huge impact on society, economy, politics, business and over the whole living animal planet as well. Not only that, he also explained the possible types, criteria and vice versa of risk factors and theorized how society will have to go through continuous adaptation and by doing that there might be numerous changes in social patterns, cultures, norms or etiquettes. According to Beck, risks create boomerang effects, which is so much relatable with this Pandemic issue. It has been more than 9 months and yet we are not on the safe side yet because of the returning effects of COVID. To get rid of risks, there should be enough actions and activities of individuals and societies through empirical decision making. I also tried to draw inspirations in my analysis from the Actor Network Theory in collective psychology. Bruno Latour's Actor Network Theory has been widely used to determine the relationship of humans and their interaction with inanimate objects. Here this pandemic is a health hazard to the whole world and the actors (peoples) are networked by this virus which supports the Actor Network Theory. Clash of risk cultures, risk perception, perceived threats and subsequent response have drawn major attention to my perspective on this topic of socio-psychological complexity.

\section{The 'New Normal' After The COVID-19 Outbreak}

Adaptive recovery or as the "New Normal "; in which we learn to live with the virus even as we look forward to medical progress in eradicating it. It is a situation when restrictions of social distancing are lifted but many people will not grasp that this is finally over. A 'New Normal' where the world will trend towards working at home, shopping at home, conferencing at home, and maybe even virtually travelling to other cities from home. There will be a trend to make one's home self-sufficient (Al-Tabbah, S. June 2020). This trend could lead to more recluses, more shut-ins, and more people who create cocoons in their homes or apartments to protect themselves from germs in the outside world. This is the time of public health emergencies. This period is the epidemic of explanations and panorama of collective disorientations. The threat to human lives urges action yet to manage this crisis seems out of our limit because of the uncertainties which challenge technological solutions and this crisis management is centered on continuous changes and rapid adaptations where available information and datas are scarce and limited.

\section{This Pandemic Is Affecting People's Psychology}

Where fear of infection could make people worried, more anxious, more germ phobic about trains, planes and shared cars; then masks will become a wardrobe priority. No kisses, no high 
fives, no handshakes or hugs (Al-Tabbah, S. June 2020). These changes will be permanent till someone wins the billion-dollar prize for a vaccine. The cost will be loss of schools, economic hardship, mass unemployment, death of small entrepreneurship business ideas, psychological pain, and shattered marriages. A crisis as huge as the Great Depression; Pandemic has been a threat to global peace and security, which is going to leave huge psychological impacts behind it. Such as stress, trauma, depression, insecurity, disbelief and so more. Not only those, but also school disruptions, disinformation, growing inequalities, cultural crisis, multilateralism challenges and unemployment. Tens of thousands of students across the world are leaving University and school into what could be one of the deepest and longest recessions we have ever seen. So, getting a job in months or years to come, would be difficult which makes sure that, job market is going to be super competitive and full of chaos till we get over from this totally. That's a lot of stress and despair to hold because people have to survive fighting these bad periods. In Israel people were hugging trees to cope with social distancing. Israel's Nature and Parks Authority told people on social media to spend time with nature to overcome one of the hardest deprivations of the pandemic such as lack of touch and intimacy. Elderly people are in the most vulnerable position as their immune system to fight with this disease is also very low. So, spending time with nature brought out the least positive vibe among them. On the other hand, spending time in nature can have a positive effect on physical and mental health, lowering heart rate and stress levels, and reducing the feeling of isolation for sure. Nobody was ready to embrace this havoc yet peoples are coping up to fight with this pandemic. The world is entering into a new phase. It is the high time for humanity to thoroughly self-reflect in a positive way.

\section{Changes In The Pattern Of Relationships In Pandemic Era}

There has been a new slang illustrated by Jessine Hein on $18^{\text {th }}$ June on the magazine The Economist. That is devoted to Cuomo sexually. When it comes to relationships, corona virus has changed everything from courtship to cohabitation: and this slang covers dating, dumping and divorce; which are prominent elements of relationship. People have been the victim of such situations and for the last 9 months they have been adapting themselves with new routines. No close physical attachment with friends or family and with loved ones; everybody is keeping distance to protect each other. Humans need physical attachment, it's most likely psychological, it's really hard for children and elderly people because they feel care, emotional security and affection through touch and sensibility. A Sociologist named Dacher Keltner from University of California studies the impact of touch and worries about the long-term impact of social distancing on singles that live alone. He contends the fabric of society is held together by even 
the smallest physical contact. Touch is as important a social condition as anything. It reduces stress; it makes people trust one another. It allows for cooperation (Dockterman, E. $11^{\text {th }}$ April, 2020).

On a general note, all kinds of relationships are going through hardships because of this distance maintaining situation. Medical service providers are keeping strict distance from their family, it is hard for kids because they surely want the touch and affection from their closed ones. Children are not allowed to play with their friends nowadays because of the virus threat and not having peer groups around also affects the emotional need of children. On the other hand elderly people are strictly confined within four walls mostly to protect them from this virus but they also need affections. Some age groups are going through hard patches and patterns of relationships are getting molded systematically. The greeting culture, blessing etiquettes are considered differently to maintain safe distance. Adults are finding alternative ways to fill up the space of affection, that's why users of social media have been high on subscription numbers. Online activities have noticeably increased from the past couple of months. When people are in solitary confinement suffering from touch deprivation, and then it is observed that, people lose a sense that someone has got their back, that they are part of a community and connected to others. People are social creatures and they will definitely find ways to continue to date, primarily via Face-time, Zoom, Meet, Skype and other video call apps. A Biological Anthropologist named Helen Fisher from Kinsey Institute has conducted hundreds of MRI scans on smitten people to see love's effect on our brains. It turns out that our brains treat romantic love as a central need like thirst and hunger (Dockterman, E. 11 ${ }^{\text {th }}$ April, 2020). To be logical, thirst and hunger aren't going to die, and neither are feelings of love and attachment that allows people to pass their DNA to the next generation. In some cases, people are also trying to be creative and trying to make a way out in a positive sense, but mostly them; who have enough resources and supporting systems to survive. Normally being jobless and alone, single people are spending more time swiping right on dating apps to find love and to keep themselves busy.

\section{Societal Complexity Pops Up}

New forms of reform are popping up. History says, pandemics have always brought change. Technologically advanced equipment is brought out to ease the daily activities during Corona without touching and maintaining physical distance. Such as using voice technology to control entryways and security. A boom to virtual reality where VR allows us to have the experiences we want even if we have to be isolated, quarantined or alone for positive psychological 
intervention. Online dating apps and availability of partners through dating apps are changing the form of love and creating plastic love culture. No commitment, no responsibilities and motive are mostly having romantic conversation through those online dating sites. Major changes in work patterns and service-based tasks through online. On the other hand, as societies try to defend themselves through severe restrictions on people's movement and interactions; this pandemic continues to decimate families, being hashed on government; crushing economies and tearing through the social sector. The interconnectedness and vulnerabilities of the complex systems that make the modern world run; which has been more apparent. Going abroad and getting back from abroad has been 20 times more complicated and harder than before because of security screening, borders have been tightened around in most countries. Therefore, it might be observed further surges in nationalist attitudes and political regimes. The growing insecurity of fresh graduates about career and mountain sized unemployment conditions pass only depression among them.

\section{Psycho-Social Epidemic}

This pandemic has spread an epitome of fear and uncertainty which has given birth to few epidemics. It is said that fear can feed on you. Irrational phobic feelings are found from everyone who sneezes or has coughed. Deep seated intuition, panic attacks, stigma and xenophobia are highly associated with suspicious irrationality alongside as the side effects of this pandemic. The epidemic of fear, the epidemic of stigmatization and moralization and lastly the epidemic of action and apatite reaction (Flaherty C, 26 $6^{\text {th }}$ May 2020) All these psycho-social epidemics need closer examination in studying the post-pandemic world. From a sociological perspective, this turns out quite interestingly that psycho-social epidemics are those that have the potential capacity to infect everyone in the society. Jon Zelner, a social epidemiologist and assistant professor of epidemiology at the University of Michigan, is working on a convergeaffiliated study about how mass incarceration and segregation impact disparities in COVID19's spread (Flaherty C, $26^{\text {th }}$ May 2020).

\section{Inequality Concerns Sociological Attention}

The Corona virus has taken charge of the world and the after effects of this pandemic are not going to leave; it will be prominent for years to come. This virus has spread through every continent, every corner of the world considering no borders, it will continue to discriminate against the most vulnerable groups. UN Secretary-General Antonio Guterres tweeted on $18^{\text {th }}$ July in Tweeter that, "We all are floating in the same sea, but some are in super yachts and 
others clinging to drifting debris". Entire regions that were making progress on eradicating poverty and narrowing inequality have been set back years, in a matter of months.

The COVID-19 outbreak affects all segments of the population and is particularly detrimental to members of those social groups in the most vulnerable situations, and continues to affect populations, including people living in poverty situations, older persons, persons with disabilities, youth, and indigenous peoples. Early evidence indicates that the health and economic impacts of the virus are being borne disproportionately by poor people. For example, homeless people, because they may be unable to safely shelter in place, are highly exposed to the danger of the virus. People without access to running water, refugees, migrants, or displaced persons also stand to suffer disproportionately both from the pandemic and its aftermath whether due to limited movement, fewer employment opportunities, increased xenophobia etc. (UN, 2020).

It cannot be avoided that the fact is, frontline service provider, health workers are at huge risk. Vulnerable groups, Elderly people and Children should be protected with utmost care; resources towards these groups are incapable to arrange protection for them unfortunately. Millions of people are discriminated against and side kicked who have no access to health care and other basic life needs and they are the majority of the total population. Under-developed countries cover the majority of the world population and they are still outside the consideration radar. They are not able to get basic human rights, let alone providing them protection from COVID. The same story goes with elder citizens; they are not given much importance by communities; this one is most likely discrimination by age. Whereas in poor countries females are exploited by their rights; discriminated by gender, we can say. Treatment, social services- these all are served by economic and social status which is structured exploitation. Systematic racism, legacy of colonialism and lack of access to technology had been entirely responsible to create inequalities on an international level and world leaders are not giving attention to that. There should be enough sociological studies and observation to bring out all forms of inequalities for making solutions for them. Lock-down periods have also made digital discrimination more prominent in developing and under-developed countries mostly, where billions of people do not have stable electricity far alone broadband internet connection, which definitely limit their ability to work, continue their education or socialize with their loved family and friends (Kiran,2020: 756-757).These all leads towards depression, stress, panic attack and criminal activities also. 


\section{Prominent Global Inequalities Came Out}

COVID-19 has highlighted few inequalities globally, which has slammed the door of humanity in so many countries, which is depressing.

1. Less or no access to healthcare

2. Less or no access to green space

3. Less or no access to the internet

4. Less or no ability to work remotely

5. Less or no accessibility for handicapped people

6. Less mobility

People from minority ethnic groups have been likely to die from COVID-19 and tragically across the world; race, gender, income and education levels of a certain community can influence how healthy they are, depending on where they live and even their life expectancy can vary up to 34 years. Well off countries tend to have more greenery space while others are struggling hard to maintain the practice of social distancing. Almost half of the world is still out of the range of the internet. When pandemic hit, billions of children worldwide were shut out from education, leaving students behind who have no home internet, ultimately they are unable to learn remotely. Getting timely information about the virus keeps people safe but communication can be difficult for people with vision, hearing or cognitive disorders. Basic needed tasks can be hard for people with certain physical disabilities. This pandemic has intensified existing systemic inequalities. Unplanned interactions produce positive emotions. Spontaneous communication with others can help with mental and physical health to encourage us to fulfill our potential and help us to find meanings in our lives.

\section{Paradigm Shift In Office Culture}

Organizational office culture is a catchy part of why employees choose to work for a company and what keeps them there for the long term. More specifically, the culture of an organization is exactly what makes them feel as though they get fit within a workplace which can affect happiness, motivation and ultimately, productivity. Managing Director of Robert Halt UK, named Matt Weston, expresses his thought on this topic that it is important for business leaders to focus on how COVID-19 is impacting working experiences and afterwards what they can do to continue to ensure a positive office culture for their staff. While there stays a certain degree of uncertainty associated with the current pandemic cycle, it is high time for a forward-thinking 
perspective of how business leaders will maintain their organizational culture ongoing. Demonstrating a range of soft skills, which are vital to create a positive, inclusive and productive working environment are going to be useful. Empathy of leaders towards individual circumstances and issues are being vigilant and responding in helping staff solve problems and challenges and maintain a positive mindset- all of which can potentially have a top-down effect.

\section{Conclusions}

COVID-19 changed our outlook, perspectives, feelings, greetings, attitudes, attachments, education, services, jobs and lives as well and the impact of it is our going to be carried for a long-time which is not precisely assumable till yet. Looks like suddenly Disney is out of magic, Paris is no longer romantic, Megacities are not busy like before, The Chinese Wall is no longer a fortress and Mecca is unbelievably empty. Hugs and kisses have become weapons and not visiting parents and friends have become an act of love, money-beauty-power-technology are worthless which cannot provide oxygen which people are fighting for. Yet days are going on, it only puts humans in cages. It has an immense effect on our psychology as it derives our expressions of love, body language, postures, physical distances, and public gatherings in a whole different way. The psychological impact of this pandemic is wide-ranging, substantial, and long lasting. It has caused tremendous psychological problems in different sub-groups. It is indeed a serious level challenge for psychological and mental health worldwide. It is really important that we stay mindful and sensitive to our mental health needs and to that of the ones we care for (Bao Y, Sun Y, Meng S, et al.2020). The COVID-19 Pandemic has presented a once-in-a-lifetime opportunity to transform the way we live. The epidemic also revealed deadly flaws in the healthcare system. .If humanity wants to solve global challenges like this; young people must play an active role and bring out the best volunteer version of them to give it a hand physically and psychologically. 


\section{References:}

Al-Tabbah, S. (2020), “Coronavirus Pandemic: Coping with the Psychological Outcomes, Mental Changes, and the 'New Normal' During and after COVID-19', p (816),www.raftpubs.com

Bao,Y., Sun,Y. \& Meng,S. (2020), “2019-CoV Epidemic: Address Mental Health Care to Empower Society”, p- 395. https://bit.ly/2TiJFch

Dockterman E. (2020), "The Coronavirus is Changing How We Date: Experts think the shifts may be permanent”, TIME Magazine US ed, www.time.com/magazine

Perry, G.k, (2012), “Documenting Disaster after Katrina: Using Online Tools to Rebuild Community,"

Beck, U. (2011),“Clash of Risk Cultures or Critique of American Universalism”. London: Sage.

Al-Basam, D. (2020), “The Corona virus: Sociology of a pandemic”, GULF TIMES Magazine, www.gulf-times.com.

Flaherty, C. (2020), “Social Scientists on COVID-19”, www.insidehighered.com

Zografos, C. (2020), “Covid recovery and radical social change”, $7^{\text {th }}$ July 2020, The Ecologist Journal, www.ecologist.com.

Beck,U.(2000), “Risk Society: Towards a New Modernity” (London: Sage Publication), p. 19. Elliott,A.(2002), “Beck’s Sociology of Risk: A Critical Assessment”, Sociology, Vol. 36, No. 2, p. 299.

Jarvis, D.S.L, (2007), "Risk, Globalisation and the State: A Critical Appraisal of Ulrich Beck and the World Risk Society Thesis”, Global Society, Vol. 21, No. 2, p.25-32.

Demirbaş, D. ,Bozkurt,V. ,Yorğun,S. (2020),“COVID-19 Pandemisinin Ekonomik, Toplumsal ve Siyasal Etkileri”, Istanbul University Publications, p.( 252-262).

Kramer, A. \& Kramer, K. Z. (2020). "The potential impact of the Covid-19 pandemic on occupational status, work from home, and occupational mobility". Journal of Vocational Behaviour, 119, 1-4.

Kiran, E. (2020), "Prominent Issues About The Social Impacts of Covid-19", Gaziantep University Journal of Social Sciences, p.(754-763). 
United Nations. (2020). "A UN framework for the immediate socio-economic response to covid19".https://www.undp.org/content/undp/en/home/coronavirus/socio-economic-impactof-covid-19.html 